doi:10.29285/actapinteriana.2020.6.11

\title{
The theological import of the metaphor of the Book of Nature: historical hallmarks and open questions
}

\author{
Giuseppe Tanzella-Nitti \\ Facoltà di Teologia Scuola Internazionale Superiore per la Ricerca Interdisciplinare (SISRI) Pontificia Università \\ della Santa Croce, Roma. \\ tanzella@pusc.it
}

Tanzella-Nitti, G. (2020): The theological import of the metaphor of the Book of Nature: historical hallmarks and open questions. A „Természet könyve”-metafora teológiai hozadéka: történelmi fordulópontok és nyitott kérdések. Acta Pintériana, 6: 11-21.

\begin{abstract}
A tanulmány célja összegezni a „Természet könyve”-metafora kutatásával kapcsolatos kérdések mai állását, különösképpen is a fundamentálteológus szempontjai szerint. A szerző a kérdés másodlagos irodalmának bemutatása nyomán hangsúlyozza, hogy a metafora iránti érdeklődés messze túlmutat a teológia területén. A liber naturae-hagyomány diakronikus szerkezetének elemzése után, a hagyomány aktualizálhatóságának problematikája köti le a szerző figyelmét. A szinkronikus és elemző tárgyaláson belül különösen érdekfeszítő a lex naturalis kérdéskör vizsgálata, amely természetes erkölcsi törvény problematikája szervesen illeszkedik az itt vizsgált tágabb hagyományba. A tanulmány a szerző korábbi írásainál terjedelmesebben kitér a „Természet könyve” - gondolat kortárs tanítóhivatali recepciójára (vö. AP 2016, pp. 55-75). A gondolatmenet a hagyomány aktualizálása szempontjából fontos hermeneutikai kérdéseket is felvázolja, miközben az egész témát elhelyezi a II. Vatikáni Zsinat által felelevenített klasszikus Logosz-teológia horizontján. Nyomtatott formában a jelen angol nyelvü szöveg magyar fordítása is elérhető (In: BAGYINSZKI Á. [ed.] [2019]: A „,Természet könyve” mint a „,Szentírás könyvének” analógiája. Konferenciakötet, Sapientia Szerzetesi Hittudományi Föiskola \& L'Harmattan, Budapest, pp. 21-48).
\end{abstract}

\section{Introduction}

Recent times have witnessed a remarkable interest in the notion of the „Book of Nature” as a locus of divine presence and revelation. In recent Magisterium of the Catholic Church, it has been most prominently mentioned by John Paul II in Fides et ratio (see JOHN PAUL II 1998, n. 19), Benedict XVI in Verbum Domini as well as in other discourses (see BENEDICT XVI 2010d, nn. 6-21; 2009d, n. 51), and Francis in Laudato si' (see FRANCIS 2015, nn. 12, 85, 239). Indeed, interest in the metaphor reaches far beyond the theological domain: for many centuries it has attracted continuing fascination in a range of contexts including literature, art and particularly the natural sciences (see for example DEBUS \& Walton 1998; Howell 2002; Pedersen 1992; Pedersen, Coyne \& Sierotowicz 2007). The metaphor seems to offer, therefore, a great opportunity to the dialogue between the human and the natural sciences, between theology and scientific culture. 
However, the metaphor and its increasing use are not without risks and challenges. On the one hand, the idea of nature or creation as a book is only an improper analogy, that is, a metaphor, which raises questions regarding the origins and the historical development of the metaphor as such, as well as its prudent and appropriate use in theology. On the other hand, the image of the Book of Nature does not seem to have obtained, in recent times, a specific theological development; in 20th century Fundamental theology the notion of revelation of God through the created world received less attention, compared with the wide room given to God's revelation through the history of salvation, centered on the religious experience of the people of Israel (see CAÑIZARES \& TANZELLA-NITTI 2006, pp. 289-335). Furthermore, the metaphor is far from having an established meaning; it has been employed within a wide range of cultural, philosophical and theological contexts for very different purposes. In Patristic and Medieval literature, nature as a book was seen in harmony with the Sacred Scriptures, whereas from the early Modern era onwards it was presented also as an autonomous book, other than biblical Revelation. Looking at the present time, a new risk of misunderstandings arises, because many webpages, institutes and programs of spirituality propose to re-evaluate, or be in tune with, the „Book of Nature”. This gives rise, for instance, to the circulation of dubious quotations, as well as the tendency to mix Christian and non-Christian sources, as if they were necessarily speaking about the same thing. For all these reasons, the use of the metaphor of nature as a book remains a delicate question. In my opinion, there is an urgent need for greater theological discernment and for good scholarly work on this so important subjectmatter.

\section{Scholarly contributions and their different perspectives: a short status quaestionis}

In general terms, the scholarship has long been dominated by linguistic and literary studies. The classic reference is that to Curtius' European Literature and the Latin Middle Ages (1948), which includes a chapter on the metaphoric uses of the book in the history of literature and quotes various (mainly Medieval) instances of nature as a book (see CURTIUS 1990, chap. 16). The metaphorical approach is applied more systematically in Rothacker's Das Buch der Natur (1979) which, however, is only a collection of citations, the majority of which are from the age of Romanticism (see ROTHACKER 1979). A third major contribution is Blumenberg's Die Lesbarkeit der Welt (1981), which uses both of the previous studies as well as other sources to provide a more systematic analysis of the history of the idea that the world is readable (see BLUMENBERG 1981). Yet Blumenberg's methodology is decidedly "metaphorological" (the term is his), and little attention is paid to the theological dimension of the question.

More recently, there have been a range of theologically orientated studies, particularly the two series of volumes edited, respectively, by Vanderjagt and van Berkel, and by van der Meer and Mandelbrote, that include historical surveys and analyses of the metaphor (see the articles in VANDERJAGT \& BERKEL 2005; VANDERJAGT \& BERKEL 2006; VAN DER MEER \& S. MANDELBROTE 2008a; 2008b). There are important contributions in these volumes, although they suffer the lack of a clear (and indeed theological) framework; moreover, the focus is overwhelmingly on Medieval and Modern sources, paying less attention to the Classical and Patristic Ages, when the metaphor was born. I proposed a more theological approach in my article The Two Books prior to the Scientific Revolution, published in 2004 (see TANZELLA-NITTI 2004, pp. 51-83) and, more recently, in a section of vol. 3 of my Treatise on Fundamental Theology in Scientific Context, published in 2018 (see TANZELLA-NITTI 2018, pp. 343450 ), which includes a chapter dedicated to the revelation of God through creation. As far as I know, 
there are no monographic studies that would set a clear framework and analyze the historical uses of the metaphor across different authors. ${ }^{1}$

On my own part, during the last 15 years I confined myself to collect quotations and bibliography, going in depth occasionally on authors such as Galileo or Robert Boyle. This material was mainly used in public lectures and seminars. However, four years ago, I planned a project of a couple of $\mathrm{PhD}$ thesis in theology aimed at exploring the metaphor in depth, from the point of view of Fundamental theology, which is my study and research field. The first fruit of such a research project is the 500-page $\mathrm{PhD}$ thesis authored by the Finnish scholar Oskari Juurikkala, which is entitled, The Patristic and Medieval metaphor of the Book of nature: implications for Fundamental theology, ready to be discussed within the current academic year. I am indebted to Oskari for part of the material I propose you in the Lecture of this first session.

\section{Historical steps and some hermeneutical clarifications}

That the subject deserves a deeper study is witnessed by the fact that the different authors are still far from reaching a common view on many aspects of the metaphor. For instance, regarding its very historical origin, Curtius and Blumenberg provide some indications that the underlying idea would be found in ancient Mesopotamia and possibly (with doubts) in ancient Greece; however the sources are not carefully analyzed by these authors, and almost the entire patristic literature is ignored, with the exception of some references to St. Augustine (354-430) (see CURTIUS 1990, pp. 302-311; BLUMENBERG 1981, chaps. 3-4). Drecoll has argued that the specific expression liber naturae (that is, the typical medieval and modern expression) is not found before Augustine (see DRECOLL in VANDERJAGT \& BERKEL 2005, pp. 35-48). Drecoll's argument can be misleading, however, because he studies a specific combination of words, whereas the concept of book is certainly applied metaphorically to created nature before Augustine, at least by Anthony, Ephrem the Syrian (c. 306-373) and Evagrius Ponticus (c. 345-399). Blowers has quite convincingly argued that the beginnings of the analogy between Scripture and cosmos as „two books” should be traced back to Origen (184/185-253/254) (see BLOWERS 2012, pp. 318-319). ${ }^{2}$ All of these arguments may even be valid in terms of the parameters set by each of the studies; but then, their variety reveals the need for a detailed and systematic analysis of the origins and gradual development of the metaphor.

Unfortunately, the literature about the theoretical foundations, in the Patristic period, of the image of nature as a book is very limited. Blowers has highlighted the centrality of the Greek notion of logos, but he didn't elaborate much on the argument, and his research is principally concerned with the spiritual dimension of theology of creation, where the metaphor can appear a peripheral matter (see BLOWERS 2012, pp. 318-322). Biblical theology is surprisingly silent on the subject, although it should be clear that the origin of all the things from the Word of God, has much to do with the idea that the various creatures can speak of their Creator, like the words of a book speak of their Author.

As far as the Medieval period is concerned, the way in which the metaphor is transmitted and received by the previous Patristic period raises some questions. In the secondary literature, the Medieval Book of Nature is routinely associated with Augustine (see for example BLUMENBERG 1981, chap. 5; NOBIS in RITTER 1971, pp. 957-959). However, it is quite probable that while this concept referred to Augustine for being the greatest of all the patristic authorities for the Latin Middle Ages, actually the

1 There are a number of interesting ideas in studies limited to individual authors. Other valuable but limited considerations may be found for example in BLOWERS in HARVEY \& HUNTER 2008, pp. 906-931; BLOWERS 2012, pp. 318-322; LOLLAR 2013, pp. 246-250.

2 This view is supported by Benjamins, who however examines a limited range of sources and provides no explicit use of the metaphor in Origen (see BENJAMINS in VANDERJAGT \& BERKEL 2005, pp. 13-20). 
underlying theological insights came from somewhere else. It seems that a key-role was played by John Scottus Eriugena (c. 810-877), who transmitted to the Latin environment, through both his own writings and translations, the ideas of the great Greek Fathers - the Cappadocians, Pseudo-Dionysius, and most importantly Maximus the Confessor. Concerning the subsequent development of the Medieval metaphor, pride of place has conventionally been given to Bonaventure (1221-1274). However, this attribution too could be somewhat misleading, because Bonaventure was essentially using ideas common in the 12th century, especially in the writings of Hugh of Saint Victor (1096-1141).

Regarding the theological foundations and implications of the Medieval metaphor, the issue may be addressed of what are the continuities and discontinuities with respect to the Patristic texts. Of course, there are significant continuities, which suggest that there is already a well-established tradition, that only undergoes small changes of emphasis and perspective. On the other part, the Middle Ages bring about at least three important novelties. First, we perceive a growing skepticism with respect to the intrinsic value and readability of nature due to the weight of sin; the issue it not entirely new, yet Augustine himself spoke of that, but it acquires now more explicit expression, enriching the metaphor with a third book, the book of the Cross. Second, while the Patristic metaphor was predominantly conceptualized in terms of the spoken word (based on the divine Logos and the logoi that the creature are), the Medieval Book of Nature (and the various sub-metaphors to which it gives rise) is increasingly presented as something which must be seen, not only heard. Third, in each period the metaphor reflects the framework offered by the theology of the period: God's call to salvation, the relationship between creation and redemption, the role of the Incarnated Word, all subjects about which the Fathers of the Church and the Middle Age authors didn't have the same and identical perspective. It is known that in the Middle Age the theological emphasis was mainly on redemption and Christology, while the language turned more symbolic and rational compared with that employed by the Fathers.

Leaving aside the understanding of the metaphor during the revival of naturalistic studies experienced by the Renaissance, the more intriguing period for studying contents and implications of the Book on Nature remains, in my opinion, the Modern Age. First of all, it must be stressed that many of the consequences which will come later into light in the 17th and 18th centuries were surprisingly prepared by the Liber creaturarum by Raymond of Sebond (1385-1436), a text that the Italian scholar Lino Conti has the merit to have underlined and commented in recent years (see CONTI 2004). The autonomy of nature, that of its own language, and the possibility of a closer vis-à-vis confrontation with the Book of Scripture, are all seeds present in Sebond's view that, probably beyond his own expectations, brought about much stronger effects during the scientific revolution. Secondly, the Modern Age is witness of very different views about the readability of the Book of Nature. A Neoplatonic perspective, inherited by the Academies of the Renaissance, which confines the usability of the Book to those who know the language of mathematics and geometry, is opposed to the perspective that considers Nature as a public book, readable by everyone. However, in this last view co-exist two different attitudes: one that states that the Author of Nature's Book is the same Author of sacred Scriptures, the other quite critical with respect to a specific divine Revelation in the history. In the Modern Age the Book of Nature could be used either to give rise to a religion of nature or to reinforce the religion of the Judaeo-Christian tradition. Among the scholars who faced this quite intriguing period it must be quoted Peter Harrison, but a systematic and exhaustive study is, at the moment, still lacking (see HARRISON 1998; 2007; HARRISON in VANDERJAGT \& BERKEL 2006, pp. 1-26).

\section{The role of the Metaphor in the frame of Fundamental theology}

The interest of Fundamental theology is not, primarily, to focus on the metaphor as a linguistic phenomenon, but to highlight the theological idea that the metaphor seeks to express. Moreover, if 
theology studies why and how nature was seen as a book, it is not for the sake of a historical curiosity, but as a way of illuminating present-day questions and discussions around the relation between faith and reason. Think, for instance, to the import that, in this respect, may have issues such as: a) the salvific value of the contemplation of nature; b) the revelation of God through creation; c) the interrelation between creation and redemption; d) biblical exegesis and the natural sciences; e) the inter-religious dialogue starting from nature, etc.

The main philological, linguistic and historical questions, propaedeutic to the theological ones, mainly regard the period from the Antiquity to the early Modern Age and could be summarized as follows: a) what are the key Patristic and Medieval texts in which the metaphor is found; b) what is their status in terms of textual critique (authenticity, expressions truly used, etc.); c) what is their true hermeneutical context (type of literature, the context in which the idea appears, motivation); and d) to which tradition the texts inherited, that is, what are their assumptions and antecedents. These questions seek to identify more precisely the relevant texts so as to enable us to analyze the historical origination, diffusion and evolution of the metaphor.

On the other hand, there are more properly theological questions, which go beyond the texts and the words used and, in a sense, go even beyond the metaphor itself, because they „open” the notion of book toward other relevant notions as logos, words, letters, voices, mirror, etc. Taking into account the broader perspective of theology, the first point to clarify is what are the underlying theological foundation and vision that give rise to the metaphor (for example, the presence of the Logos in creation, allegorical exegesis, sacramental theology based on symbolic language, etc.). Only after this previous analysis, Fundamental theology can address its more relevant questions and implications. They are, in my opinion, the following: a) who is able to read the Book of Nature and how should it be read; b) what is the relationship between the Book of Nature and the book of Scripture; c) does the Book of Nature have any moral and/or salvific relevance for those who read it; and d) what does the Book of Nature reveal about God, his nature, his will and his salvific plans for all mankind. In all of these questions, theology is highly interested in investigating the Christological dimension of this book. In other words, what the metaphor means and the extent to which it can be used, must depend, in its deeper and ultimate level, on the Christological understanding of creation, of the Scriptures and of the human being.

Let's go more in depth into the two properly theological issues here mentioned, namely the very foundation of the metaphor and their implications for today's Fundamental theology.

There is a number of elements in Patristic theology that seem to provide a solid theological basis for the grounding and further development of the metaphor. The most important of these was the correspondence between the cosmological logos of Greek philosophy and the biblical idea of the divine word of creation. Other ideas, such as the existence of a natural law (understood both cosmically and morally), the contemplation and beauty of nature as a work of God, and the practice of allegorical interpretation of Scriptures, may also have contributed to the success of the metaphor. The historical studies have confirmed all these elements. Although we cannot definitively determine the role and influence of each author, nevertheless we can state without doubt that the theology of the divine Word, that is the role of Logos in the work of creation, is central to the Patristic and Medieval idea of nature as a book; it is repeatedly found in the context of theology of creation, and over time it becomes more and more clearly expressed in the idea of the logoi that the creatures are. In contrast, the significance of the other elements is more varied. For instance, the natural law is particularly important to Maximus, and it plays a role in Ephrem; but it is quite marginal in Bonaventure, probably because his extensive doctrine of the natural law was mainly confined to its interior dimension. The notion of the contemplation of nature, on the other hand, is found in numerous texts, and it is important to most of the thinkers. Allegory is present in some cases, but many times the metaphor is not based on any allegory at all; rather, it is derived from a parallelism between Scriptures and creation, which is much more than an allegory, 
having Scriptures and creation the same origin and finality in the divine Logos. Even the authors of the Middle Age, who bent toward a symbolic language, as Scottus Eriugena, Hugh of St. Victor and Bonaventure, do not derive the metaphor from symbolic considerations only.

If we consider pre-Christian texts, they provide of course some preparation to the Christian metaphor of the Book of Nature, but confine themselves to heavenly characters. The religiosity of many ancient cultures spontaneously attributed a certain divinity to the heavens, which were understood as the place for a dialogue between the god(s) and the human beings. However, it was only the Christian doctrine of the Incarnated Logos that enabled to understand that the divine presence and communication may have been sought and found in all created realities, without any loss of divine transcendence. The Christian understanding (and transformation) of the cosmological logos of Greek philosophers was fundamental for this new vision, because it provided the conceptual tools for distinguishing between the transcendent (non-immanent) Logos and the created logoi, the latter of which are not identified with the Logos, but are inseparable from him, and therefore intrinsically related to all the creative, revelatory and redemptive activity of the divine Logos, Jesus Christ.

\section{The contemporary revival of the Book of nature in the teachings of the Catholic Church: chances and uncertainties}

Concerning the implications of the metaphor for today's Fundamental theology it should be noted that some of them are intrinsic to the view of nature as ,a book”, while others refer to idea of having two books, namely Nature and Scripture, authored by the same God. In the first case, considering nature as a book is a fruitful image, because it easily associates to the created world all the characters of a true divine revelation. In fact, a book manifests the person/personality of its Author; it transmits a Word and expresses an intentionality; it contains an intelligible message; it is communicable and universal even though it does not dispense with a certain work of interpretation; it is able to rise the interest of the addressee and demands for his answer; its origin is a person and it is directed to a personal interlocutor. These all are important characteristics that help to understand Nature as the place of a true divine revelation, and would suffice to justify the interest of theology toward those approaches and authors, in the past as well in the present times, who have employed or still use the metaphor.

The pontifical Magisterium of recent decades seems to have seized this opportunity, at least judging by the high number of references to the Book of Nature in documents of certain relevance. In a page of Fides et ratio (1998), John Paul II defines this book as ,the first stage of divine Revelation [...] which, when read with the proper tools of human reason, can lead to knowledge of the Creator" (n. 19); an idea he resumed and developed during a couple of Wednesday catechesis, given on occasion of General Audiences (cf. JOHN PAUL II 2000; 2002).

Benedict XVI quotes the metaphor in the encyclical Caritas in veritate (2009) (cf. n. 51), and speaks of it widely in the post-synodal exhortation Verbum Domini (2010).

In this last document, he states that ,while the Christ event is at the heart of divine revelation, we also need to realize that creation itself, the liber naturae, is an essential part of this symphony of many voices in which the one word is spoken" (n. 7); then, he adds, ,, we can compare the cosmos to a 'book' [...], the work of an author who expresses himself through the 'symphony' of creation" (n. 13). There are about a dozen speeches by this Pontiff - addresses, catechesis and speeches of various kinds - which speak of nature as a book that the Creator offered to us. Benedict XVI often uses this image to point out that the rationality of creation and the rationality of the human mind, capable of understanding it, both have their origin in God (cf. for instance BENEDICT XVI 2005; 2008; 2009a; 2009c; 2009b; 2010b; 2010a; 2010c; 2013). The metaphor is well present also in pope Francis Encyclical Laudato si' (2015): 


\section{„God has written a precious book - the Pontiff says - whose letters are the} multitude of created things present in the universe." (N. 85; cf. nn. 6, 11, 239) $)^{3}$

One element deserves to be highlighted here. The author most frequently mentioned by the Magisterium of the popes is, in this context, Galileo Galilei, who also uses the metaphor, as we shall see later, in various places in his works (cf. JOHN PAUL II, 1998, n. 34, footnote 29; BENEDICT XVI 2006; 2008; 2009c; 2010d, n. 30). Is there any particular reason to refer to Galileo, given the wide choice of possible authors, including many Fathers of the Church, many Medieval theologians and not a few Modern authors? The question is not irrelevant, bearing in mind the long history of the metaphor and the specific use that Galileo makes of it, according to the Neo-platonic view of the Renaissance Academies. I believe that this choice is only the result of a kind of „overexposure” of the Galileo affair, an author that the Catholic Church likes to mention when she deals with issues related to the natural sciences. Galileo's sentences are well known and, perhaps, also materially more available than quotations coming from other sources, even if more "pertinent. Moreover, Galileo is an emblematic figure: when the Magisterium quotes his passages about God as the author of the book of the world, it wants to endorse the harmony between science and faith by employing the same words of the Italian scientist. However, when it is done without providing further details, the complex history of the metaphor runs the risk to be put by parenthesis; similarly, the differences between the way in which Galileo makes use of the metaphor and the use made by other authors before him, the Fathers of the Church in particular, seem to be underestimated.

In the second case, when the metaphor refers to the „Two Books”, Nature and Scripture, theology is easily induced to employ it just to frame the relationship between faith and reason, or that between faith and science, within a captivating image, clear to a wide public. Here too, Galileo remains the most cited source. However, if we look closely, the question is much more delicate than we think. In fact, if the image of the "Two Books" is used to express the two modalities of the same divine Revelation, namely revelation through creation and revelation through the biblical message, we must not forget that, in Catholic theology, the book of Scripture cannot express, by alone, the entire historical-supernatural Revelation. Unlike the theological currents born from the Protestant Reformation, Catholic theology highlights the role of Tradition, which is considered fully part of divine Revelation, as Scripture does. For these reasons, centering the whole faith and reason relationship on the metaphor of the Two Books seems reductive, and somewhat misleading.

\section{A task for Fundamental theology}

Are all these difficulties and subtle clarifications strong enough to prevent today's Fundamental theology from speaking fruitfully of Nature as a book written by God? If we don't want to use the adjective ,ambiguous” when we speak of the Book of Nature, we should at least acknowledge that a theologian would face a multi-layers image, having different meanings. The tricky and problematic heritage of the very concept of ,nature”, one of the most complex subject-matter in all the history of ideas, adds more troubles to an already problematic issue. If theologians confine themselves to the domain of theology of Revelation, the history of metaphor, as we know, shows at least four different ways of referring to the Book of Nature. They are in turn:

a) Thanks to this book, the knowledge of the Creator, of whom biblical revelation speaks about, is extended to all, in a very accessible way, making known to all the fundamental moral requirements that derive from the existence of a Creator; Nature is therefore proposed as a true form of divine revelation, comprehensible, effective and universal.

3 The metaphor was proposed also in the Homily on the Solemnity of Epiphany (FRANCIS 2014). 
b) This book confirms, in a certain way, the reasonableness of the religious and moral teachings contained in Sacred Scripture, showing that these are also available to those who observe the natural order of things and the laws which rule it. The image of the „Two Books”, then, stresses the uniqueness of their Author.

c) This book shows the self-sufficiency of a natural moral order with respect to the teachings contained in the biblical revelation, placing the latter by parentheses, or declaring it superfluous.

d) The Book of Nature indicates a field of competence reserved only for the scholars of the natural sciences, because of the specific and restrictive language in which the book is written; the image of the „Two Books”, can endorse a break between the rational and mathematical study of the world and the view of creation given by philosophy, theology, or by the Bible itself.

At the same time, notwithstanding the complex history of the metaphor and the different meanings it has acquired, I suggest that theology must also acknowledge some interesting and precise „lines of thought". They seem to resist the diversification of the hermeneutics proposed and to overcome the differences and purposes with which the image has been used. Three main ideas that the metaphor conveys, seem to persist along the history and are shared by most of the authors: namely the Book of Nature is universal (the language of mathematics, in a sense, continues to express a dimension of universality); it has an Author (other images of nature, as mother, or a living being, etc., do not primarily refer to any author); the image has been widely used by scientists because it has many things to say to the activity of science, in the past as well as in the present.

First, the idea that nature is in front of our eyes like an open book, a public book that everyone can read, even if not everyone knows how to interpret it immediately, is a shared content that persists through all epochs with different emphasis. The sky is above all of us, the earth is under the eyes of all. Everyone comes across nature, because it is our common home. We need not to look for this book, because it comes to meet us. Somehow it reveals itself. It speaks to someone with its illustrations, to others with its arguments, to others more showings its laws, whether of a physical or moral order. On closer inspection, even if we were to recognize that it is written in mathematical characters and think its reading reserved only for those who know its language, we would not deny its universality. Rationality and science still have a public dimension because everyone, in principle, can be educated to have access at this knowledge. In contemporary society, where the suggestion of the unknown and the search for secret mysteries too often replace the true religious sense, the call to the universality of divine revelation in a book available to all can help to avoid this dangerous drift. And in this task science and theology find themselves on the same side, because they are both interested in reason, that is, in the Logos at basis of the Book's readability.

Second, those who have used for centuries the metaphor of nature as a Book, or also the metaphor of the „Two Books" to include a comparison with Scripture, they all have accepted, at least implicitly, the possibility of thinking of a personal Author. For the materialist and the atheist, closed to any possible transcendence, nature is certainly not a book, but only a place of conflict and irrationality, the theatre of pure chance, something which looks absurd. Knowing the reasons why the metaphor has been used, would allow theology of Revelation to better understand where and why implicit or explicit references to an Author of the Book were born, helping the interlocutor (including scientists) to evaluate which Subjects are philosophically adequate to play the role of an intelligent and personal author. It should be noticed that the reference to the ,author" was not denied even by those who, throughout history, emphasized the self-sufficiency of the Book or defended the autonomy of scientific work; at least until the rise of 19th century materialism, none of these prerogatives of nature was affirmed against the existence of God. Within the rich framework of the metaphor, theology could help scientists to recognize 
the many consequences which stem from the belief that in the very foundation of physical reality there is a personal author: the effect of a personal writer, the universe is readable, it is rational and lawful, conveys a message, embodies a purpose; in a word, it reflects what a book is and what a book means.

Third and last, the dialogue between theology and the natural sciences can be fostered by the historical fecundity of the metaphor of the „Two Books" - albeit the limits and the hermeneutical warnings already highlighted. Contrary to a rather widespread cliché, the scientific revolution did not mark a break between the Two Books, but rather gave voice to a need for greater intelligibility of both. There is a consolidated tradition, even among the witnesses of the newborn scientific method, from Francis Bacon to Tommaso Campanella, from Galileo Galilei to Robert Boyle, according to which the Book of Nature helps the understanding of the Book of Scripture and the latter maintains unchanged its moral and spiritual value for our lives. Precisely because the author of the two books is the same, with the development of the sciences new questions arose and new implications came to light. These not only concerned, evidently, biblical exegesis, but concerned creation as a whole, which to scientific observations now appeared with an extent, richness and complexity previously unimaginable. Scientific discoveries claimed - and in a certain way will always ask for - a re-reading of the Book of Scripture. Beyond the inaccuracies and misunderstandings that the Copernican affaire showed on both sides, the call that Galileo addressed to theologians will be addressed by other men of science in the following centuries on new important issues, from Darwin to Freud. At the same time also Scripture can suggest scientists to read again and better the Book of Nature, not to interfere with the scientific method, but to help them distinguishing what in that Book speaks to science and what, instead, speaks to the existential and religious dimensions of the human being, what is written in the characters of mathematics and what, instead, is written in the language of wisdom. A scientist like Robert Boyle, for example, was able to make these different readings, showing how they complemented each other.

In conclusion, I hope that a Fundamental theology which operates in a scientific context like ours, could appraise all the richness that the metaphor still have and use it more fruitfully.

\section{References}

BENEDICT, XVI (October 18, 2006): Discourse to National Assembly of the Italian Church. Verona.

BENEDICT, XVI (May 27, 2010a): Discourse to the General Assembly of the Italian Bishop Conference. BENEDICT, XVI (October 31, 2008): Discourse to the Pontifical Academy of Sciences, Rome.

BENEDICT, XVI (December 22, 2005): Discourse to the Roman Curia.

BENEDICT, XVI (February 6, 2013): General Audience.

BENEDICT, XVI (March 24, 2010b): General Audience.

BENEDICT, XVI (November 7, 2010c): Homily in the Church of the „Sagrada Familia”, Barcelona.

BENEDICT, XVI (January 6, 2009a): Homily on the Solemnity of the Epiphany, Rome.

BENEDICT, XVI (December 8, 2009b): Message for the World Day of Peace. „If you want to cultivate peace, protect creation".

BENEDICT, XVI (November 26, 2009c): Message to the Participants to the Conference „From Galileo's Telescope to Evolutionary Cosmology", Rome.

BENEDICT, XVI (September 30, 2010d): Verbum Domini (Apostolic Exhortation).

BENEDICT, XVI (June 29, 2009d): Caritas in Veritate (Encyclical Letter).

Benjamins, R. (2005): The Analogy between Creation and the Biblical Text in Origen of Alexandria. In: A. VANDERJAGT \& K. van BERKEL (eds.) (2005): The Book of Nature in Antiquity and the Middle Ages. Peeters, Leuven, pp. 13-20.

Blowers, P. M. (2008): Doctrine of Creation. In: S. A. HARVEY \& D. G. HunTER (eds.) (2008): The Oxford Handbook of Early Christian Studies. Oxford UP, Oxford - New York, pp. 906-931. 
doi: 10.1093/oxfordhb/9780199271566.003.0045

Blowers, P. M. (2012): Drama of the Divine Economy. Creator and Creation in Early Christian Theology and Piety. Oxford UP, Oxford. doi:10.1093/acprof:oso/9780199660414.001.0001

BLUMENBERG, H. (1981): Die Lesbarkeit der Welt. Suhrkamp, Frankfurt.

CAÑIZARES, J. S. \& G. TANZELlA-NiTTI (2006): La rivelazione di Dio nel creato nella Teologia della rivelazione del XX secolo. Annales Theologici, 20:289-335.

CONTI, L. (2004): L'infalsificabile libro della natura alle radici della scienza. Porziuncola, Assisi.

CURTIUS, E. R. (1990): European Literature and the Latin Middle Ages. Princeton UP, Princeton. doi: $10.1515 / 9781400846153$

Debus, A. G. \& M. T. WALTON (eds.) (1998): Reading the Book of Nature. The Other Side of the Scientific Revolution. Sixteenth Century Journal Publishers, Kirksville (Mo).

DRECOLL, V. H. (2005): „Quasi Legens Magnum Quendam Librum Naturae rerum” (Augustine: Contra Faustum 32,20). The Origin of the Combination Liber Naturae in Augustine and Chrysostomus. In: A. VANDERJAGT \& K. van BERKEL (eds.) (2005): The Book of Nature in Antiquity and the Middle Ages. Peeters, Leuven, pp. 35-48.

FRANCIS (May 24, 2015): Laudato si' (Encyclical Letter).

FRANCIS (January 6, 2014): Homily on the Solemnity of Epiphany. Rome.

HARrison, P. (1998): The Bible, Protestantism and the Rise of Natural Science, Cambridge UP, Cambridge. doi: 10.1017/CBO9780511585524

HARRISON, P. (2006): The „Book of Nature” and Early Modern Science. In: A. VANDERJAGT \& K. van BERKEL (eds.) (2006): The Book of Nature in Early Modern and Modern History. Peeters, Leuven, pp. 1-26.

HARRISON, P. (2007): The Fall of Man and the Foundations of Science. Cambridge UP, Cambridge. doi: $10.1017 / \mathrm{cbo} 9780511487750$

Howell, K. J. (2002): God's Two Books. Copernican Cosmology and Biblical Interpretation in Early Modern Science. University of Notre Dame Press, Notre Dame (IN).

JOHN PAUL, II (August 2, 2000): General Audiences.

JOHN PAUL, II (January 30, 2002): General Audiences.

JoHn PAUL, II (September 14, 1998): Fides et Ratio (Encyclical Letter).

LOllar, J. (2013): To See into the Life of Things. The Contemplation of Nature in Maximus the Confessor and his Predecessors. Brepols, Turnhout. doi: 10.1484/M.MON-EB.5.112293

NOBIS, H. M. (1971): Buch der Natur. In: J. RITTER et al. (eds.) (1971): Historisches Wörterbuch der Philosophie. vol. 1., Schwabe, Basel, pp. 957-959. [online] https://www.schwabeonline.ch/schwabexaveropp/elibrary/start.xav?qn=\%24\%24\%240penURL\%24\%24\%24\&id=doi\%3A10.24894\%2FH WPh.512\#_elibrary_\%2F\%2F*\%5B\%40attr_id\%3D\%27verw.buch.der.natur\%27\%5D_157745 5539623. doi:10.24894/HWPh.512

Pedersen, O. (1992): The Book of Nature. Vatican Observatory Publications - University of Notre Dame Press, Città del Vaticano - Notre Dame (IN).

Pedersen, O.; G. V. Coyne \& T. Sierotowicz (2007): The Two Books. Historical Notes on Some Interactions Between Natural Science and Theology. Vatican Observatory Foundation - University of Notre Dame Press, Città del Vaticano - Notre Dame (IN).

ROTHACKER, E. (1979): Das Buch der Natur. Materialien und Grundsätzliches zur Metapherngeschichte. Perpeet, Bonn. (ed. Wilhelm Perpeet)

Tanzella-NitTI, G. (2018): Teologia Fondamentale in Contesto Scientifico. vol. 3., Religione e Rivelazione. Città Nuova, Roma, pp. 343-450.

TanZella-NitTI, G. (2004): The Two Books prior to the Scientific Revolution. Annales Theologici, 18:51-83. 
VAN DER MEer, J. M. \& S. MANDElbrote (eds.) (2008a): Nature and Scripture in the Abrahamic Religions. vol. 1., Up to 1700. Brill, Leiden. doi:10.1163/ej.9789004171916.i-782

VAN DER MeER, J. M. \& S. MANDELbRote (eds.) (2008b): Nature and Scripture in the Abrahamic Religions. vol. 2., 1700-Present. Brill, Leiden. doi:10.1163/ej.9789004171923.i-618

VANDERJagt, A. \& K. VAN Berkel (eds.) (2005): The Book of Nature in Antiquity and the Middle Ages. Peeters, Leuven.

VAnderJagt, A. \& K. VAn Berkel (eds.) (2006): The Book of Nature in Early Modern and Modern History. Peeters, Leuven. 